\title{
Structural Analysis of $\mathrm{Na}_{2} \mathrm{O}-\mathrm{B}_{2} \mathrm{O}_{3}$ Melts by Pulsed Neutron Total Scattering Method and Molecular Dynamics Simulation
}

\author{
Yoshifumi KITA, Masakatsu MISAWA, ${ }^{1)}$ Norimasa UMESAKI, ${ }^{2)}$ Tadashi KIRIHARA, ${ }^{3)}$ Toshiharu \\ FUKUNAGA $^{4)}$ and Takamichi IIDA
}

Department of Materials Science and Processing, Faculty of Engineering, Osaka University, Yamadaoka, Suita, Osaka-fu, 565 Japan.

1) National Laboratory for High Energy Physics, Oho, Tsukuba, Ibaraki-ken, 305 Japan.

2) Government Industrial Research Institute, Osaka, Midorigaoka, Ikeda, Osaka-fu, 563 Japan.

3) Formerly Graduate School, Osaka University. Now at Nippon Steel Corporation, Shimada, Hikari, Yamaguchi-ken, 743 Japan.

4) Department of Crystalline Materials Science, Faculty of Engineering, Nagoya University, Furo-cho, Chikusa-ku, Nagoya, Aichi-ken, 464 Japan.

(Received on June 15, 1992; accepted in final form on September 18, 1992)

In order to obtain direct information on the structure of sodium borate melts which are of use in metallurgical processes, pulsed neutron total scattering measurements have been carried out on $10 \mathrm{~mol}_{2} \mathrm{Na}_{2} \mathrm{O}-$ and $30 \mathrm{~mol} \% \mathrm{Na}_{2} \mathrm{O}-\mathrm{B}_{2} \mathrm{O}_{3}$ melts at $1073 \mathrm{~K}$, in addition to the previous measurement on pure $\mathrm{B}_{2} \mathrm{O}_{3}$ melt. Molecular dynamics (MD) calculations have also been made on pure $\mathrm{B}_{2} \mathrm{O}_{3}$ and $30 \mathrm{~mol} \% \mathrm{Na}_{2} \mathrm{O}-\mathrm{B}_{2} \mathrm{O}_{3}$ melts at $1073 \mathrm{~K}$.

With increase in $\mathrm{Na}_{2} \mathrm{O}$ content, the first peak of $R D F(r)$, representing B-O correlation, spread asymmetrically to larger $r$ side, and the coordination number of $O$ atoms around a reference $B$ atom $n_{\mathrm{B}-\mathrm{O}}$ increased from 3.0 to 3.5 , showing variation of $\mathrm{B}-\mathrm{O}$ correlation. This increase in $n_{\mathrm{B}-\mathrm{O}}$ could be explained by the simple assumption that two $\mathrm{BO}_{3}$ triangle structure units are converted to two $\mathrm{BO}_{4}$ tetrahedron structure units with the addition of one $\mathrm{Na}_{2} \mathrm{O}$ molecule in the same way as in $\mathrm{Na}_{2} \mathrm{O}-\mathrm{B}_{2} \mathrm{O}_{3}$ glasses. These $n_{\mathrm{B}-0}$ values also agreed well with those obtained by $\mathrm{MD}$ calculations, which showed the clear evidence of the appearance of $\mathrm{BO}_{4}$ units that the distribution of $\mathrm{O}-\mathrm{B}-\mathrm{O}$ bond angle spread from $120^{\circ}$ to smaller anlge side for $30 \mathrm{~mol} \% \mathrm{Na}_{2} \mathrm{O}-\mathrm{B}_{2} \mathrm{O}_{3}$.

From these results, it is safely concluded that a part of $\mathrm{BO}_{3}$ triangle structure units is converted to $\mathrm{BO}_{4}$ tetrahedron structure units with the addition of $\mathrm{Na}_{2} \mathrm{O}$ up to $30 \mathrm{~mol} \%$ to $\mathrm{B}_{2} \mathrm{O}_{3}$ melt in the same way as in $\mathrm{Na}_{2} \mathrm{O}-\mathrm{B}_{2} \mathrm{O}_{3}$ glasses.

KEY WORDS: $\mathrm{Na}_{2} \mathrm{O}-\mathrm{B}_{2} \mathrm{O}_{3}$ melt; sodium borate; structure; structure unit; pulsed neutron scattering; molecular dynamics, MD calculation.

\section{Introduction}

A precise knowledge of the structure and properties of $\mathrm{B}_{2} \mathrm{O}_{3}$-based melts and glasses is required increasingly from the fundamental and practical viewpoints. Among binary borate glasses, alkali borate glasses have long been absorbing the attention of many researchers because of "borate anomaly" shown in the composition dependence of some physical properties. $\mathrm{Na}_{2} \mathrm{O}-\mathrm{B}_{2} \mathrm{O}_{3}$ system has also been attractive for its practical use in metallurgical processes. Therefore, many investigations have been performed on the structure of $\mathrm{Na}_{2} \mathrm{O}-\mathrm{B}_{2} \mathrm{O}_{3}$ glasses by means of X-ray diffraction, ${ }^{1)}$ Raman spectroscopy, ${ }^{2,3)} \mathrm{NMR}^{4,5)}$ and thermal expansion. ${ }^{6)}$

Previsouly, one of the authors carried out a pulsed neutron scattering study on the temperature dependence of the structure of pure $\mathrm{B}_{2} \mathrm{O}_{3}$ galsses and melts. ${ }^{7)}$ Several other diffraction studies have been reported on the structure of pure $\mathrm{B}_{2} \mathrm{O}_{3}$ melt. $^{8-11)}$ However, high temperature diffraction studies on the structure of
$\mathrm{Na}_{2} \mathrm{O}-\mathrm{B}_{2} \mathrm{O}_{3}$ melts have not yet been reported to the authors' knowledge, although physical properties such as the density, ${ }^{12-14)}$ viscosity, ${ }^{15,16)}$ surface tension ${ }^{17)}$ and the velocity of sound ${ }^{18)}$ have been measured widely on $\mathrm{Na}_{2} \mathrm{O}-\mathrm{B}_{2} \mathrm{O}_{3}$ melts. An attempt has been made recently by Derno et al. ${ }^{19\}}$ to reveal the structure of $\mathrm{Na}_{2} \mathrm{O}-\mathrm{B}_{2} \mathrm{O}_{3}$ melts by comparing the X-ray diffraction data on rapidly quenched $\mathrm{Na}_{2} \mathrm{O}-\mathrm{B}_{2} \mathrm{O}_{3}$ glasses and normally cooled glasses.

In the present study, pulsed neutron total scattering experiments have been carried out on $\mathrm{Na}_{2} \mathrm{O}-\mathrm{B}_{2} \mathrm{O}_{3}$ melts, in order to investigate the structural change of these melts with the addition of $\mathrm{Na}_{2} \mathrm{O}$. Molecular dynamics (MD) simulation has also been made on these melts for comparison with the diffraction experiments.

\section{Experimental}

Pulsed neutron scattering experiments have been carried out on $10 \mathrm{~mol} \% \mathrm{Na}_{2} \mathrm{O}-$ and $30 \mathrm{~mol} \% \mathrm{Na}_{2} \mathrm{O}-$ 


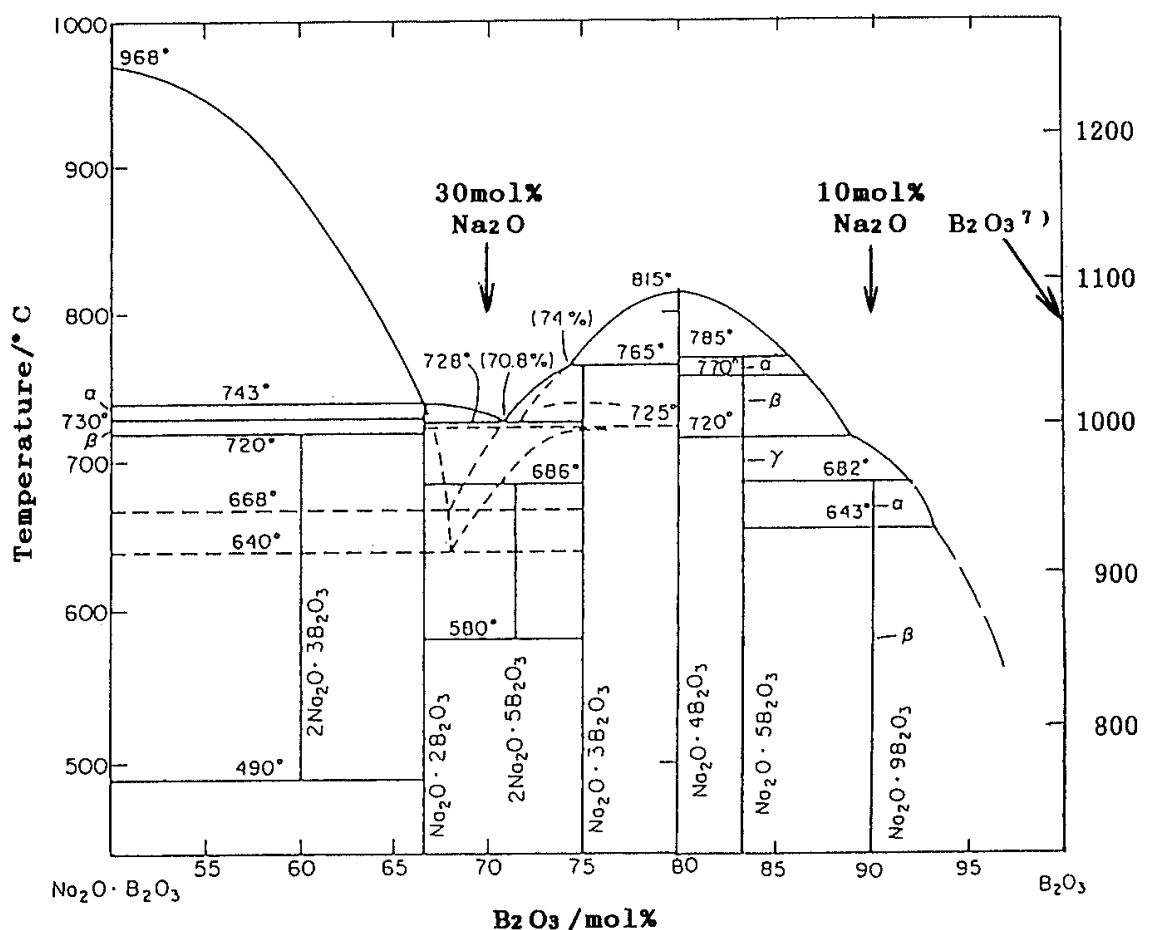

范

Fig. 1.

The phase diagram of $\mathrm{Na}_{2} \mathrm{O}-\mathrm{B}_{2} \mathrm{O}_{3}$ system. ${ }^{20)}$ Arrows show the temperatures and compositions of the specimens measured.
$\mathrm{B}_{2} \mathrm{O}_{3}$ melts at $1073 \mathrm{~K}$ with time-of-flight (TOF) method by using the high intensity total scattering spectrometer (HIT) installed at a pulsed spallation neutron source at National Laboratory for High Energy Physics (KEK) in Tsukuba. The temperatures and compositions of measured specimens are indicated in Fig. 1 showing the phase diagram of $\mathrm{Na}_{2} \mathrm{O}-\mathrm{B}_{2} \mathrm{O}_{3}$ system. ${ }^{20}$ )

The smaples were prepared by the following procedure. $\mathrm{B}_{2} \mathrm{O}_{3}$ glass was prepared from boric acid $\left(\mathrm{H}_{3} \mathrm{BO}_{3}\right)$ enriched with $99.61 \mathrm{at} \%{ }^{11} \mathrm{~B}$, in order to avoid extremely high neutron absorption of ${ }^{10} \mathrm{~B} . \mathrm{H}_{3} \mathrm{BO}_{3}$ was melted and dehydrated in a platinum crucible in a vacuum furnace at $1073 \mathrm{~K}$ under $10^{-3}$ Torr for more than $8 \mathrm{~h}$ to produce $\mathrm{B}_{2} \mathrm{O}_{3}$ glass. The mixture of $\mathrm{Na}_{2} \mathrm{CO}_{3}(99.5 \%)$ and $\mathrm{B}_{2} \mathrm{O}_{3}$ with a given composition was heated and melted for dehydration and decarboxylation in a Pt crucible with a lid at $1373 \mathrm{~K}$ for more than $4 \mathrm{~h}$, and then poured into cylindrical copper mold to form a cylindrical sample of $7 \mathrm{~mm}$ diameter.

In the scattering experiment, the sample was contained in a thin-walled cylindrical Pt cell $(8 \mathrm{~mm}$ in inner diameter and $0.1 \mathrm{~mm}$ thick), and held at $1073 \mathrm{~K}$ by heating with infrared image furnace under reduced pressure of about 0.1 Torr. The scattering intensity spectra were obtained for the sample contained in the cell, and for the blank cell. The incident neutrons were scattered by the sample, and the scattered neutrons were detected by the ${ }^{3} \mathrm{He}$ counters located at several scattering angles, i.e. $2 \theta=8^{\circ}, 13^{\circ}, 24^{\circ}, 30^{\circ}, 42^{\circ}, 90^{\circ}$ and $150^{\circ}$. The time-of-flight scattering intensity spectra were recorded on a hard disk using a computer-controlled data-acquisition system, and then processed by use of a computer at KEK. As the time-of-flight corresponds to the wave length of a pulsed neutron, $\lambda$, the scattering intensity can be obtained as a function of the magnitude of the scattering vector or the momentum transfer, $Q=4 \pi \sin \theta / \lambda$, where $2 \theta$ is the scattering angle.
The scattering intensity for the sample in the $\mathrm{Pt}$ cell was corrected for the cell, background, absorption, and multiple and incoherent scatterings. The coherent scattering intensities $I(Q)$ were normalized using the scattering intensities from the vanadium rod, since coherent scattering length of $\mathrm{V}$ is negligibly small.

The interference function $S(Q)$ in the Faber-Ziman form $^{21)}$ is obtained as follows:

$$
S(Q)=\frac{\left[I(Q)-\left\{\sum\left(c_{i} b_{i}^{2}\right)-\left(\sum c_{i} b_{i}\right)^{2}\right\}\right]}{\left(\sum c_{i} b_{i}\right)^{2}}
$$

where $b_{i}$ is the coherent scattering length of the $i$-th nuclei, $\left(b_{\mathrm{B}}=6.65, b_{\mathrm{O}}=5.805\right.$ and $\left.b_{\mathrm{Na}}=3.63 \times 10^{-15} \mathrm{~m}^{22}\right)$ and $c_{i}$ the atomic fraction. The pair distribution function $g(r)$ is obtained by Fourier transform of the structure function $Q(S(Q)-1)$ :

$$
g(r)=1+\frac{1}{2 \pi^{2} r \rho_{0}} \int_{0}^{Q_{\max }} Q(S(Q)-1) \sin (Q r) d Q
$$

where the number density $\rho_{0}$ was evaluated from the density values ${ }^{12)}$ of $\mathrm{Na}_{2} \mathrm{O}-\mathrm{B}_{2} \mathrm{O}_{3}$ melts. The radial distribution function $R D F(r)$ is determined by the definition.

$$
R D F(r)=4 \pi r^{2} \rho_{0} g(r)
$$

\section{Molecular Dynamics Simulation}

Molecular dynamics (MD) simulation has been carried out on pure $\mathrm{B}_{2} \mathrm{O}_{3}$ melt and $30 \mathrm{~mol} \% \mathrm{Na}_{2} \mathrm{O}-\mathrm{B}_{2} \mathrm{O}_{3}$ melt at $1073 \mathrm{~K}$, in order to investigate the detailed 3-dimensional configuration of atoms in the melts.

The MD calculations were performed in a smilar way to that used previously by one of the authors. ${ }^{23)}$ The pair potential functions were assumed to consist of a simplified Coulombic and a repulsion terms: 


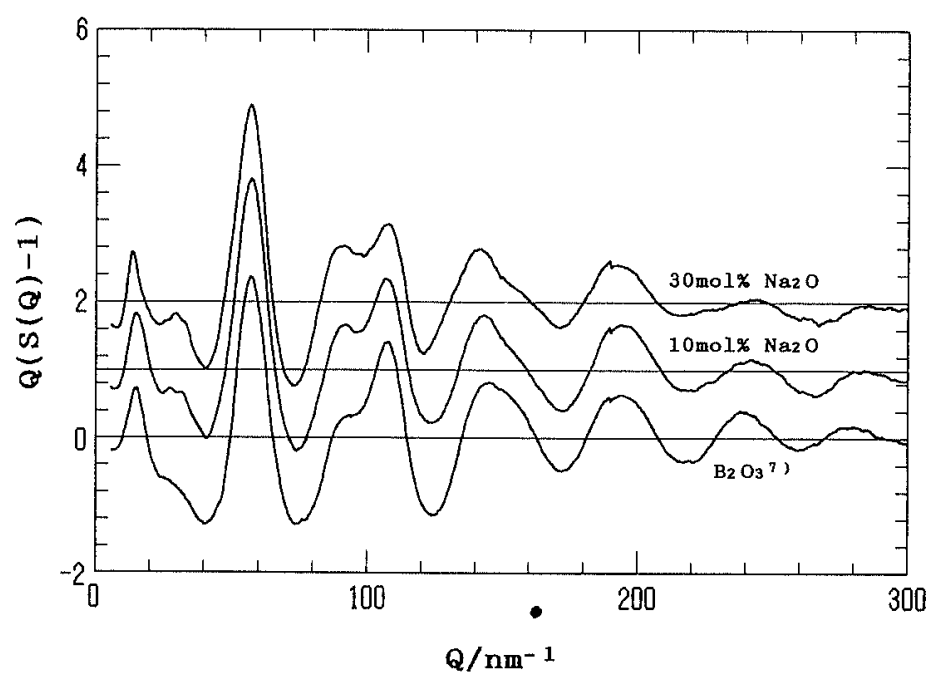

Fig. 2.

Experimental structure functions $Q(S(Q)-1)$ for $\mathrm{Na}_{2} \mathrm{O}$ $\mathrm{B}_{2} \mathrm{O}_{3}$ melts at $1073 \mathrm{~K}$.

Table 1. Peak positions of $S(Q)$ curves.

\begin{tabular}{cccc}
\hline Melt $/ \mathrm{mol} \%$ & $1 \mathrm{st} / \mathrm{nm}^{-1}$ & $2 \mathrm{nd} / \mathrm{nm}^{-1}$ & $3 \mathrm{rd} / \mathrm{nm}^{-1}$ \\
\hline $\mathrm{B}_{2} \mathrm{O}_{3}$ & 13.1 & 29.4 & 57.0 \\
$10 \mathrm{Na}_{2} \mathrm{O}-90 \mathrm{~B}_{2} \mathrm{O}_{3}$ & 13.1 & 29.4 & 56.9 \\
$30 \mathrm{Na}_{2} \mathrm{O}-70 \mathrm{~B}_{2} \mathrm{O}_{3}$ & 13.2 & 29.6 & 56.9 \\
\hline
\end{tabular}

$$
\phi_{i j}=\frac{z_{i} z_{j} e^{2}}{r_{i j}}+f_{0}\left(\beta_{i}+\beta_{j}\right) \exp \left[\frac{\left(a_{i}+a_{j}-r_{i j}\right)}{\left(\beta_{i}+\beta_{j}\right)}\right]
$$

where, $z_{i}$ : the formal charge number of ion $i$

$$
\text { (e.g., }+3 \text { for } \mathrm{B}^{3+} \text { ion) }
$$

$e:$ the unit charge

$r_{i j}$ : the distance between ion $i$ and $j$

$f_{0}$ : a force constant arbitrarily taken here to be $1 \mathrm{kcal} \cdot \mathrm{mol}^{-1} \cdot \AA^{-1}\left(=6.948 \times 10^{-6}\right.$ dyn)

$a_{i}, \beta_{i}$ : the crystal radius and compressibility of ion $i$, respectively.

The potential parameters proposed by $\mathrm{Xu}$ et $\mathrm{al}^{2{ }^{24)}}$ were used for the MD calculations. The edge length of the basic cell (a cube) was calculated from the density ${ }^{12)}$ of the melt. The number of particles (atoms) within the basic cell was about 1000 (B: $400 ; \mathrm{O}: 600$ for $\mathrm{B}_{2} \mathrm{O}_{3}$, and B: $280 ; \mathrm{O}: 480 ; \mathrm{Na}: 120$ for $30 \mathrm{~mol} \% \mathrm{Na}_{2} \mathrm{O}-\mathrm{B}_{2} \mathrm{O}_{3}$ ). In evaluating the potential energy and the force, the Coulombic term was calculated by the Ewald method. The MD calculations were carried out at the computer center of Government Industrial Research Institute, Osaka. The results of calculation were compared with those of neutron diffraction experiments.

\section{Results and Discussion}

$Q(S(Q)-1)$ curves obtained from the experiments for $\mathrm{B}_{2} \mathrm{O}_{3},{ }^{7)} 10 \mathrm{~mol} \% \mathrm{Na}_{2} \mathrm{O}$ and $30 \mathrm{~mol} \% \mathrm{Na}_{2} \mathrm{O}-\mathrm{B}_{2} \mathrm{O}_{3}$ melts at $1073 \mathrm{~K}$ are compared in Fig. 2 in the wide range of $Q$ up to $300 \mathrm{~nm}^{-1}$. The peak positions of $S(Q)$ curves are given in Table 1. With the addition of $\mathrm{Na}_{2} \mathrm{O}$ to $\mathrm{B}_{2} \mathrm{O}_{3}$ melt, the peak positions and the overall shapes of $Q(S(Q)-1)$ curves remained almost unchanged, and the oscillatory behavior of $Q(S(Q)-1)$ in the high $Q$ region is clearly observed, with appreciable damping in

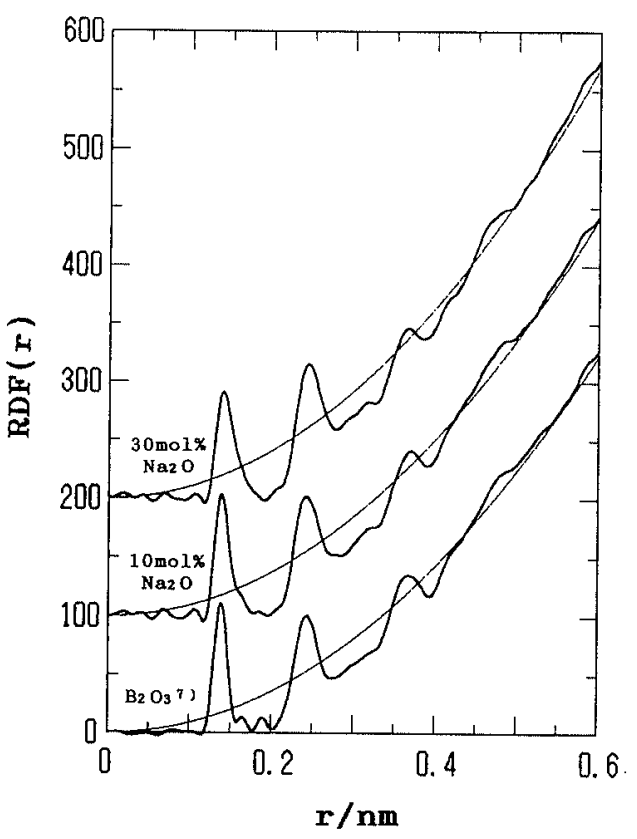

Fig. 3. Radial distribution functions $R D F(r)$ for $\mathrm{Na}_{2} \mathrm{O}-\mathrm{B}_{2} \mathrm{O}_{3}$ melts at $1073 \mathrm{~K}$.

Table 2. Peak positions of $R D F(r)$ and FWHM of the first peak.

\begin{tabular}{ccccc}
\hline Melt $/ \mathrm{mol} \%$ & $1 \mathrm{st} / \mathrm{nm}$ & $2 \mathrm{nd} / \mathrm{nm}$ & $3 \mathrm{rd} / \mathrm{nm}$ & $\mathrm{FWHM} / \mathrm{nm}$ \\
\hline $\mathrm{B}_{2} \mathrm{O}_{3}$ & 0.137 & 0.238 & 0.360 & 0.018 \\
$10 \mathrm{Na}_{2} \mathrm{O}-90 \mathrm{~B}_{2} \mathrm{O}_{3}$ & 0.138 & 0.241 & 0.370 & 0.021 \\
$30 \mathrm{Na}_{2} \mathrm{O}-70 \mathrm{~B}_{2} \mathrm{O}_{3}$ & 0.139 & 0.244 & 0.364 & 0.026 \\
\hline
\end{tabular}

amplitude with increase in $\mathrm{Na}_{2} \mathrm{O}$ content.

The radial distribution functios $R D F(r)$ obtained by Fourier transform of the experimental $Q(S(Q)-1)$ truncated at about $300 \mathrm{~nm}^{-1}$ are compared in Fig. 3 . The three peaks are clearly observed for each of $R D F(r)$. The peak positions and the full width at half maximum (FWHM) of the first peak are given in Table 2. With increase in $\mathrm{Na}_{2} \mathrm{O}$ content from zero to $30 \mathrm{~mol} \%$, the first peak position of $R D F(r)$, representing the atomic spacing of B-O, shifted gradually from 0.137 to 0.139 $\mathrm{nm}$, and the first peak broadened asymmetrically, spreading to larger $r$ side as shown in Fig. 3. 


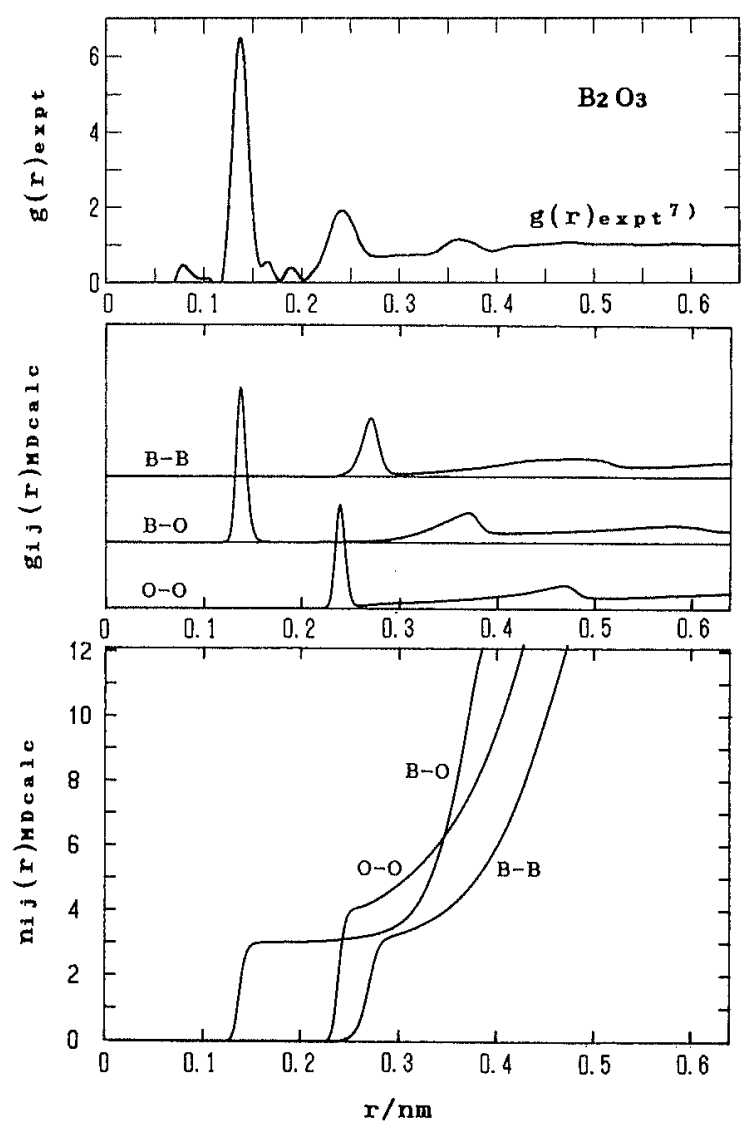

Fig. 4. Experimental total pair distribution function $g(r)_{\text {expt }}$ compared with partial pair distribution function $g_{i j}(r)_{\text {MDeale }}$ and distribution of coordination numbers $n_{i j}(r)_{\text {MDcalc }}$ by MD calculations. $\left(\mathrm{B}_{2} \mathrm{O}_{3}\right.$ melt at I $\left.073 \mathrm{~K}\right)$

The total piar distribution functions $g(r)$ obtained from the experimental $Q(S(Q)-1)$ for $\mathrm{B}_{2} \mathrm{O}_{3}{ }^{7)}$ and $30 \mathrm{~mol} \% \mathrm{Na}_{2} \mathrm{O}-\mathrm{B}_{2} \mathrm{O}_{3}$ are compared in Figs. 4 and 5 with the partial pair distribution function $g_{i j}(r)$ and the distribution of the coordination number $n_{i j}(r)$ obtained from MD calculations. The experimental $g(r)$ corresponds well to the calculated $g_{i j}(r)$, which serve as a reference in attributing the peaks of $R D F(r)$ to specific atomic bonds. In Fig. 6, $Q(S(Q)-1)$ for $\mathrm{B}_{2} \mathrm{O}_{3}{ }^{7)}$ and $30 \mathrm{~mol} \% \mathrm{Na}_{2} \mathrm{O}-\mathrm{B}_{2} \mathrm{O}_{3}$ obtained from the experiments are compared with those obtained from inverse Fourier transform of $g(r)$ of MD calculations. Both of $Q(S(Q)-1)$ are coincide with each other fairly well.

As described in the previous paper on the structure of $\mathrm{B}_{2} \mathrm{O}_{3}$ melt, ${ }^{7)}$ and also as can be seen in Figs. 4 and 5 , the first peak of $R D F(r)$ is attributed to the $\mathrm{B}-\mathrm{O}$ bond. The coordination number of $\mathrm{O}$ atoms around a reference $\mathrm{B}$ atom, $n_{\mathrm{B}-\mathrm{O}}$, is determined from the area, $A_{1}$, under the first peak of experiemental $R D F(r)$ using a relationship as follows:

$$
A_{1}=\frac{2 b_{\mathrm{B}} b_{\mathrm{O}}}{\langle b\rangle^{2}} c_{\mathrm{B}} n_{\mathrm{B}-\mathrm{O}}
$$

The coordination number of $B$ atoms around a reference $\mathrm{O}$ atom was evaluated from the relationship $c_{\mathrm{O}} n_{\mathrm{O}-\mathrm{B}}=$ $c_{\mathrm{B}} n_{\mathrm{B}-\mathrm{O}}$. The experimental values of the coordination numbers $n_{\mathrm{B}-\mathrm{O} \text { (expt) }}$ and $n_{\mathrm{O}-\mathrm{B}(\text { expt) }}$ determined by Eq. (5) are shown in Table 3. With the addition of $\mathrm{Na}_{2} \mathrm{O}$ to
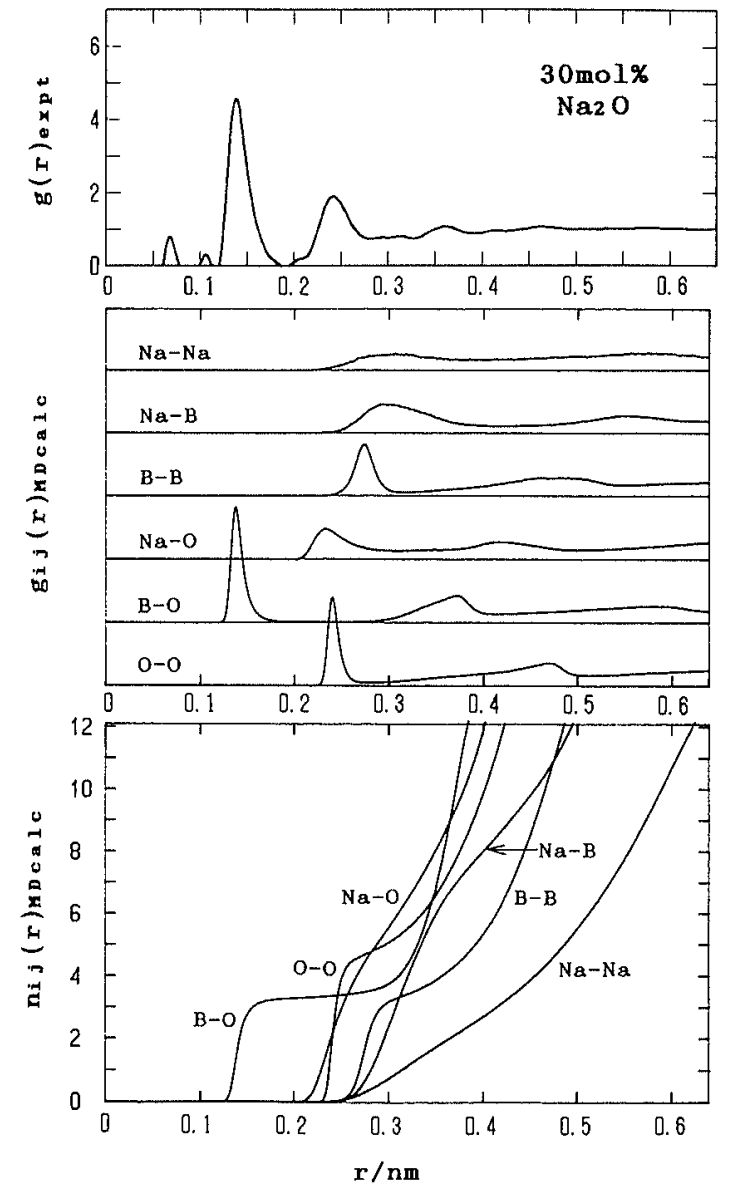

Fig. 5. Experimental total pair distribution function $g(r)_{\text {expt }}$ compared with partial pair distribution function $g_{i j}(r)_{\text {MDcalc }}$ and distribution of coordination numbers $n_{i j}(r)_{\text {MDcalc }}$ by MD calculations. $\left(30 \mathrm{~mol}^{2} \% \mathrm{Na}_{2} \mathrm{O}-\mathrm{B}_{2} \mathrm{O}_{3}\right.$ melt at $1073 \mathrm{~K}$ )

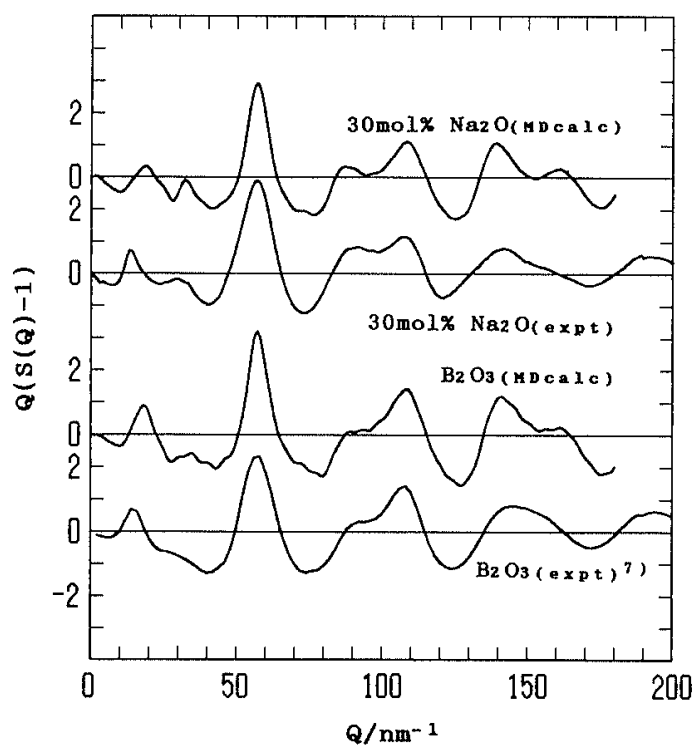

Fig. 6. Comparison of structure functions $S(S(\mathrm{Q})-1)$ obtained by experiments and by $\mathrm{MD}$ calcualtions, for $\mathrm{B}_{2} \mathrm{O}_{3}$ and $30 \mathrm{~mol} \% \mathrm{Na}_{2} \mathrm{O}-\mathrm{B}_{2} \mathrm{O}_{3}$ melts at $1073 \mathrm{~K}$.

$\mathrm{B}_{2} \mathrm{O}_{3}$, the coordination number $n_{\mathrm{B}-\mathrm{O}}$ increased from 3.0 to 3.5 , showing variation of the configuration of $\mathrm{O}$ atoms around a reference $B$ atom. These values correspond well to those of MD calcultions, as seen from 
Figs. 4 and 5 as a plateau of $n_{\mathrm{B}-\mathrm{o}}(r)$ curves ( 3.0 for $\mathrm{B}_{2} \mathrm{O}_{3}$ and 3.3 for $30 \mathrm{~mol}^{\%} \mathrm{Na}_{2} \mathrm{O}$ ).

As regards the structure of alkali borate glasses, $\mathrm{R}_{2} \mathrm{O}-\mathrm{B}_{2} \mathrm{O}_{3}$, it has been established that the structure unit, $\mathrm{BO}_{3}$ triangle, constructing boroxol ring and partly random network structure in $\mathrm{B}_{2} \mathrm{O}_{3}$ glasses, is converted to tetrahedron $\mathrm{BO}_{4}$ by the addition of $\mathrm{R}_{2} \mathrm{O}$ to $\mathrm{B}_{2} \mathrm{O}_{3}$ up to $33 \%$. According to the $\operatorname{Raman}^{2,3)}$ and $\mathrm{NMR}^{4,5)}$ spectroscopic studies, by the addition of one molecule of $\mathrm{Na}_{2} \mathrm{O}$ to the $\mathrm{B}_{2} \mathrm{O}_{3}$ glass, two $\mathrm{BO}_{3}$ units are converted into two $\mathrm{BO}_{4}$ units as shown below schematically: ${ }^{3)}$<smiles>CO[PH]1([O-])OB(O)OB([18O])O1</smiles>

If the structure units in $\mathrm{Na}_{2} \mathrm{O}-\mathrm{B}_{2} \mathrm{O}_{3}$ melts are converted from $\mathrm{BO}_{3}$ to $\mathrm{BO}_{4}$ by the addition of $\mathrm{Na}_{2} \mathrm{O}$ in the same way as in $\mathrm{Na}_{2} \mathrm{O}-\mathrm{B}_{2} \mathrm{O}_{3}$ glasses, the fraction of threecoordinated and four-coordnated B atoms, $N_{3}$ and $N_{4}$, respectively, can be expressed as follows:

$$
N_{3}=\frac{1-2 x}{1-x}, \quad N_{4}=\frac{x}{1-x}
$$

where $x$ is the mole fraction of $\mathrm{Na}_{2} \mathrm{O}$. Accordingly, the coordination number of $\mathrm{O}$ atoms around a reference $\mathrm{B}$ atom is:

$$
n_{\mathrm{B}-\mathrm{o}}=3 N_{3}+4 N_{4}=3+\frac{x}{1-x}
$$

The coordination number of $\mathrm{B}$ atoms around a reference $\mathrm{O}$ atom is:

$$
n_{\mathrm{O}-\mathrm{B}}=\frac{c_{\mathrm{B}}}{c_{\mathrm{O}}} n_{\mathrm{B}-\mathrm{O}}=2
$$

Table 3. Area under the first peak of $R D F(r), A_{1}$, and the experimental and calculated coordination number $n_{\mathrm{B}-\mathrm{O}}$ and $n_{\mathrm{O}-\mathrm{B}}$.

\begin{tabular}{cccccc}
\hline $\mathrm{Melt} / \mathrm{mol} \%$ & $A_{1}$ & $n_{\mathrm{B}-\mathrm{O} \text { (expt) }}$ & $n_{\mathrm{B}-\mathrm{O} \text { (calc) }}$ & $n_{\mathrm{O}-\mathrm{B} \text { (cxpt) }}$ & $n_{\mathrm{O}-\mathrm{B} \text { (calc) }}$ \\
\hline $\mathrm{B}_{2} \mathrm{O}_{3}$ & 2.43 & 3.0 & 3.0 & 2.0 & 2.0 \\
$10 \mathrm{Na}_{2} \mathrm{O}-90 \mathrm{~B}_{2} \mathrm{O}_{3}$ & 2.58 & 3.2 & 3.1 & 2.0 & 2.0 \\
$30 \mathrm{Na}_{2} \mathrm{O}-70 \mathrm{~B}_{2} \mathrm{O}_{3}$ & 2.59 & 3.5 & 3.4 & 2.0 & 2.0
\end{tabular}
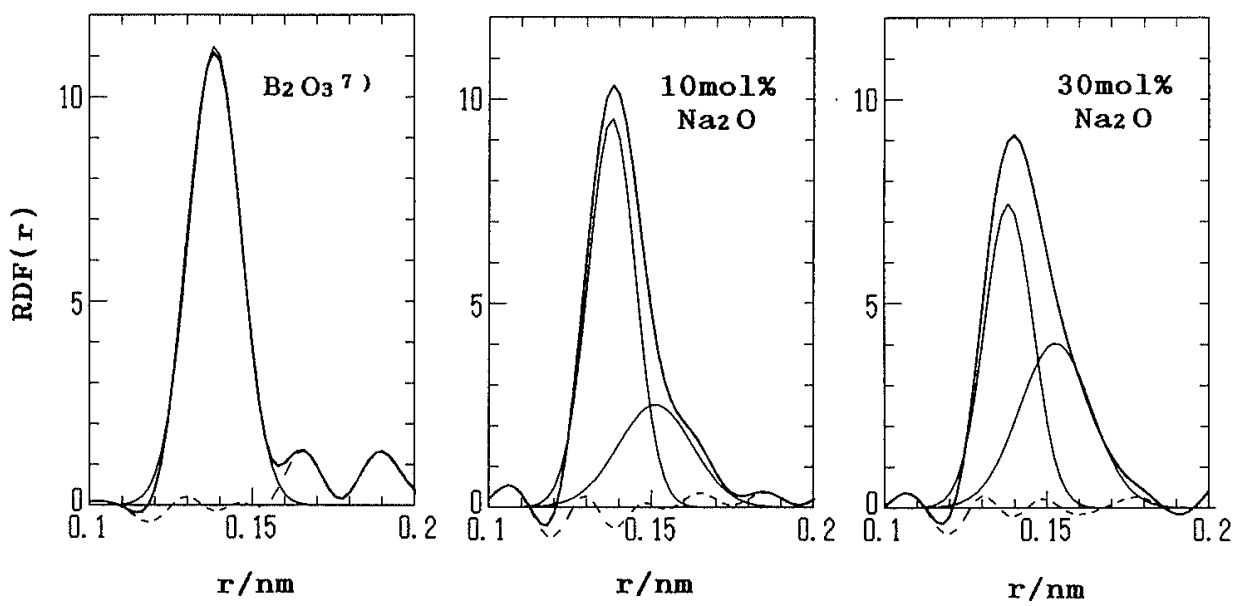

Fig. 7.

Decomposition of the first peak of $R D F(r)$ into Gaussian profile components of $R D F(r) / r$. The peak positions of the resultant curves are $0.138 \mathrm{~nm}$ for $\mathrm{B}_{2} \mathrm{O}_{3}, 0.137$ and 0.150 $\mathrm{nm}$ for $10 \mathrm{~mol}_{0} \mathrm{Na}_{2} \mathrm{O}$, and 0.138 and $0.152 \mathrm{~nm}$ for $30 \mathrm{~mol} \% \mathrm{Na}_{2} \mathrm{O}$ melts. 

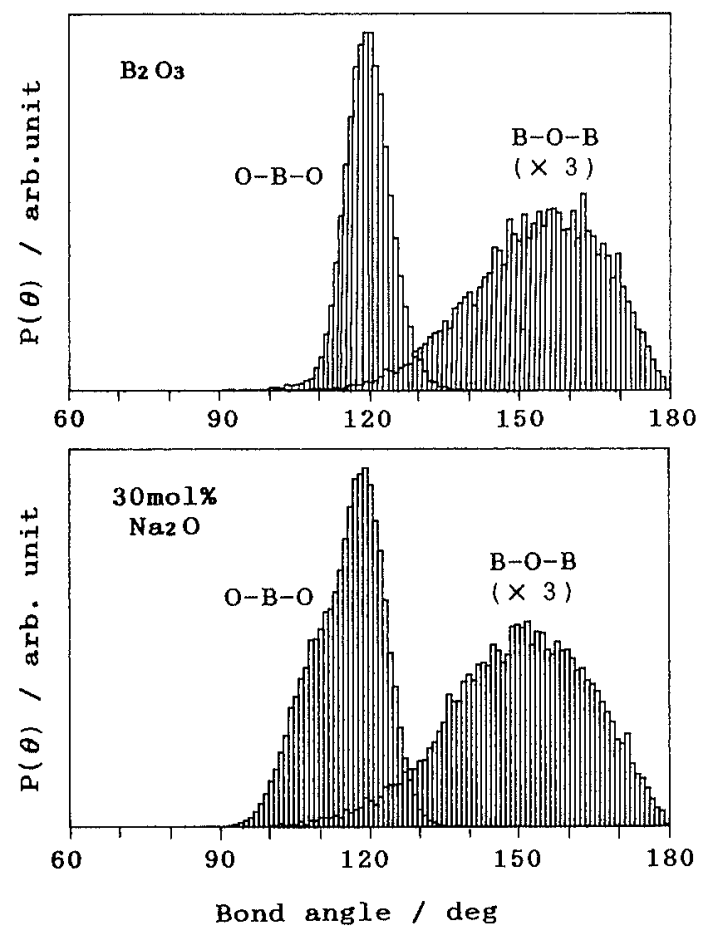

Fig. 8. The histograms of probability distribution $P(\theta)$ of $\mathrm{O}-\mathrm{B}-\mathrm{O}$ and $\mathrm{B}-\mathrm{O}-\mathrm{B}$ bond angles in $\mathrm{B}_{2} \mathrm{O}_{3}$ and $30 \mathrm{~mol} \% \mathrm{Na}_{2} \mathrm{O}-\mathrm{B}_{2} \mathrm{O}_{3}$ melts.

Table 4. The coordination number of $\mathrm{B}$ atoms around a reference $\mathrm{B}$ atom, $n_{\mathrm{B}-\mathrm{B}}$, and that of $\mathrm{O}$ atoms around an $\mathrm{O}$ atom, $n_{\mathrm{O}-\mathrm{o}}$.

\begin{tabular}{ccc}
\hline $\mathrm{Melt} / \mathrm{mol} \%$ & $n_{\mathrm{B}-\mathrm{B}}$ & $n_{\mathrm{O}-\mathrm{O}}$ \\
\hline $\mathrm{B}_{2} \mathrm{O}_{3}$ & 3.0 & 4.0 \\
$10 \mathrm{Na}_{2} \mathrm{O}-90 \mathrm{~B}_{2} \mathrm{O}_{3}$ & 3.1 & 4.2 \\
$30 \mathrm{Na}_{2} \mathrm{O}-70 \mathrm{~B}_{2} \mathrm{O}_{3}$ & 3.4 & 4.9 \\
\hline
\end{tabular}

$\mathrm{Na}_{2} \mathrm{O}$ is asymmetric and spreads to a lower angle side, corresponding to $109^{\circ}$ of a tetrahedron, showing the conversion of a part of the $\mathrm{BO}_{3}$ triangles to $\mathrm{BO}_{4}$ tetrahedra.

It can be safely deduced from the results mentioned above, that a part of the $\mathrm{BO}_{3}$ triangle structure units is converted to $\mathrm{BO}_{4}$ tetrahedron units with the addition of $\mathrm{Na}_{2} \mathrm{O}$ to $\mathrm{B}_{2} \mathrm{O}_{3}$ melt in the same way as in $\mathrm{Na}_{2} \mathrm{O}-\mathrm{B}_{2} \mathrm{O}_{3}$ glasses.

The second peak in $R D F(r)$ also provides information on the structure of $\mathrm{Na}_{2} \mathrm{O}-\mathrm{B}_{2} \mathrm{O}_{3}$ melts. The second peak is considered to reflect mainly $\mathrm{O}-\mathrm{O}, \mathrm{B}-\mathrm{B}$, and $\mathrm{Na}-\mathrm{O}$ atomic correlations, as judged from the partial pair distribution functions by MD calculations shown in Fig. 5. At first, as to B-B correlation, it is reasonable to suppose that each of four-coordinated B atoms has four neighboring $B$ atoms, while each of three-coordinated $\mathbf{B}$ atoms has three neighboring $\mathrm{B}$ atoms. Accordingly,

$$
n_{\mathrm{B}-\mathrm{B}}=4 N_{4}+3 N_{3}=3+\frac{x}{1-x}
$$

Secondly, as to $\mathrm{O}-\mathrm{O}$ correlation, the coordination number of $\mathrm{O}$ atoms around a reference $\mathrm{O}$ atom was evaluated under the following assumptions: Each of
Table 5. The area under the second peak of $R D F(r), A_{2}$, that of $\mathrm{B}-\mathrm{B}$ and $\mathrm{O}-\mathrm{O}$ contribution, $A_{2}^{\prime}$ and the difference, $\Delta A_{2}$

\begin{tabular}{cccc}
\hline Melt $/$ mol\% & $A_{2}$ & $A_{2}^{\prime}$ & $\Delta A_{2}$ \\
\hline $\mathrm{B}_{2} \mathrm{O}_{3}$ & $4.0_{0}$ & $3.5_{5}$ & $0.4_{5}$ \\
$10 \mathrm{Na}_{2} \mathrm{O}-90 \mathrm{~B}_{2} \mathrm{O}_{3}$ & $4.0_{3}$ & $3.7_{1}$ & $0.3_{2}$ \\
$30 \mathrm{Na}_{2} \mathrm{O}-70 \mathrm{~B}_{2} \mathrm{O}_{3}$ & $5.3_{4}$ & $4.1_{2}$ & $1.2_{2}$
\end{tabular}

four-coordinated B atoms has four nearest B atoms, while each of three-coordinated $B$ atoms has three nearest $\mathrm{B}$ atoms. Furthermore, both of these nearest $\mathrm{B}$ atoms consist of four-coordinated and three-coordinated $\mathrm{B}$ atoms, the ratio of which is proportional to their concentrations. Under these assumptions, the following equation can be derived:

$$
\begin{aligned}
n_{\mathrm{O}-\mathrm{o}} & =N_{4}\left(6 N_{4}+5 N_{3}\right)+N_{3}\left(5 N_{4}+4 N_{3}\right) \\
& =\left(\frac{x}{1-x}\right) \cdot\left(\frac{5-4 x}{1-x}\right)+\left(\frac{1-2 x}{1-x}\right) \cdot\left(\frac{4-3 x}{1-x}\right)
\end{aligned}
$$

$n_{\mathrm{B}-\mathrm{B}}, n_{\mathrm{O}-\mathrm{O}}$ calculated by Eqs. (9) and (10) are shown in Table 4. With the addition of $\mathrm{Na}_{2} \mathrm{O}$ up to $30 \mathrm{~mol} \%$ into $\mathrm{B}_{2} \mathrm{O}_{3}$, the coordination numbers, $n_{\mathrm{B}-\mathrm{B}}$ and $n_{\mathrm{O}-\mathrm{O}}$, increase from 3.0 to 3.4 and from 4.0 to 4.9 , respectively. These values correspond well to those of MD calculations, as seen from Figs. 4 and 5 as plateaus of $n_{\mathrm{B}-\mathrm{B}}(r)$ and $n_{\mathrm{O}-\mathrm{o}}$ curves, respectively. The area, $A_{2}^{\prime}$, under the second peak contributed by $n_{\mathrm{B}-\mathrm{B}}$ and $n_{\mathrm{O}-\mathrm{O}}$ is calculated from the following relation:

$$
A_{2}^{\prime}=c_{\mathrm{B}} \frac{b_{\mathrm{B}}^{2}}{\langle b\rangle^{2}} n_{\mathrm{B}-\mathrm{B}}+c_{\mathrm{O}} \frac{b_{\mathrm{O}}^{2}}{\langle b\rangle^{2}} n_{\mathrm{O}-\mathrm{O}}
$$

The area $A_{2}$ under the second peak of the experimental $R D F(r)$ is defined here as the integration from $0.20 \mathrm{~nm}$ to the second minimum of the $R D F$ cruve, i.e., 0.276 , 0.288 and $0.282 \mathrm{~nm}$ respectively for $\mathrm{B}_{2} \mathrm{O}_{3}, 10 \mathrm{~mol} \% \mathrm{Na}_{2} \mathrm{O}$ and $30 \mathrm{~mol} \% \mathrm{Na}_{2} \mathrm{O}$ melts. The values of $A_{2}$ and $A_{2}^{\prime}$ are listed in Table 5, with the difference between them: $\Delta A_{2}=A_{2}-A_{2}^{\prime}$. If $\Delta A_{2}$ of 10 and $30 \mathrm{~mol} \% \quad \mathrm{Na}_{2} \mathrm{O}$ is regarded as the area contributed by $\mathrm{Na}-\mathrm{O}$ bond, the coordination number of $\mathrm{O}$ atoms around a reference $\mathrm{Na}$ atom, $n_{\mathrm{Na}-\mathrm{o}}$, can be evaluated from the following relation:

$$
\Delta A_{2}=2 \cdot c_{\mathrm{Na}} \frac{b_{\mathrm{Na}} \cdot b_{\mathrm{O}}}{\langle b\rangle^{2}} n_{\mathrm{Na}-\mathrm{O}}
$$

The values of $n_{\mathrm{Na}-\mathrm{o}}$ calculated from Eq. (12) are 6.7 for $10 \mathrm{~mol} \% \mathrm{Na}_{2} \mathrm{O}$ and 7.1 for $30 \mathrm{~mol} \% \mathrm{Na}_{2} \mathrm{O}$ melts. Thus, roughly speaking, each $\mathrm{Na}$ atom is coordinated by about 6-7 oxygen atoms.

\section{Conclusions}

Pulsed neutron total scattering measurements have been carried out on $10 \mathrm{~mol} \% \mathrm{Na}_{2} \mathrm{O}-$ and $30 \mathrm{~mol} \% \mathrm{Na}_{2} \mathrm{O}-$ $\mathrm{B}_{2} \mathrm{O}_{3}$ at $1073 \mathrm{~K}$. Data on pure $\mathrm{B}_{2} \mathrm{O}_{3}$ melt were used from the previous experiment at the same conditions. Molecular dynamics (MD) calculations were also made 
on pure $\mathrm{B}_{2} \mathrm{O}_{3}$ and $30 \mathrm{~mol} \% \mathrm{Na}_{2} \mathrm{O}-\mathrm{B}_{2} \mathrm{O}_{3}$ melts for reference.

The first peak of $R D F(r)$, attributed to $\mathrm{B}-\mathrm{O}$ bond, spread asymmetrically to larger $r$ side, and the coordination number of $\mathrm{O}$ atoms arround a reference $\mathrm{B}$ atom $n_{\mathrm{B}-\mathrm{o}}$ increased from 3.0 to 3.5 with increase in $\mathrm{Na}_{2} \mathrm{O}$ content, showing the change of $\mathrm{B}-\mathrm{O}$ correlation.

The experimental values of $n_{\mathrm{B}-\mathrm{o}}$ agreed well with those calculated on the assumption that two triangle $\mathrm{BO}_{3}$ units are converted to two $\mathrm{BO}_{4}$ tetrahedron units with the addition of one $\mathrm{Na}_{2} \mathrm{O}$ molecule as in $\mathrm{Na}_{2} \mathrm{O}-$ $\mathrm{B}_{2} \mathrm{O}_{3}$ glasses.

Sufficient agreement was also found between experiment and $\mathrm{MD}$ calculation, on the results of $n_{\mathrm{B}-\mathrm{o}}$, experimental $g(r)$ and calculated $g_{i j}(r)$, and $Q(S(Q)-1)$. MD calculations also showed that the distribution of bond angle of $\mathrm{O}-\mathrm{B}-\mathrm{O}$ for $\mathrm{B}_{2} \mathrm{O}_{3}$ melt was concentrated about $120^{\circ}$, while that for $30 \mathrm{~mol} \% \quad \mathrm{Na}_{2} \mathrm{O}-\mathrm{B}_{2} \mathrm{O}_{3}$ melt shifted to lower angle side, showing appearance of $\mathrm{BO}_{4}$ tetrahedra.

From these results, it is deduced that a part of $\mathrm{BO}_{3}$ triangle units in $\mathrm{B}_{2} \mathrm{O}_{3}$ melt is converted to $\mathrm{BO}_{4}$ tetrahedron units with increase in $\mathrm{Na}_{2} \mathrm{O}$ content up to $30 \mathrm{~mol} \%$, as in $\mathrm{Na}_{2} \mathrm{O}-\mathrm{B}_{2} \mathrm{O}_{3}$ glasses.

The coordination numbers $n_{\mathrm{B}-\mathrm{B}}$ and $n_{\mathrm{O}-\mathrm{o}}$ were found to be similar to those from MD calculations. The coordination number of $\mathrm{O}$ atoms around a reference $\mathrm{Na}$ atom, $n_{\mathrm{Na}-\mathrm{o}}$, was estimated to be about 6-7.

\section{REFERENCES}

1) G. Herms et al.: J. Non-Cryst. Solids, 88 (1986), 381

2) W. L. Konijnendijk and J. M. Stevels: J. Non-Cryst. Solids, 18 (1975), 307.

3) W. L. Konijnendijk and J. M. Stevels: Borate Glasses (Mater. Sci. Res. Vol. 12), ed. by L. D. Pye, V. D. Fréchette and N. J. Kreidl, Plenum, New York, (1978), 259.
4) P. J. Bray and J. G. O'Keefe: Phys. Chem. Glasses, 4 (1963), 37.

5) G. E. Jellison, Jr and P. J. Bray: J. Non-Cryst. Solids, 29 (1978), 187.

6) J. E. Shelby: J. Am. Ceram. Soc., 66 (1983), 225.

7) M. Misawa: J. Non-Cryst. Solids, 122 (1990), 33

8) F. Herre and H. Richter: Z. Naturforsch., 12a (1957), 545

9) J. Zarzycki: Borate Glasses (Mater. Sci. Res. Vol. 12), ed. by L. D. Pye, V. D. Fréchette and N. J. Kreidl, Plenum, New York, (1978), 201.

10) Y. Waseda: Can. Metall. Q., 20 (1981), 57.

11) M. Miyake and T. Suzuki: J. Chem. Soc., Faraday. Trans. I, 80 (1984), 1925.

12) L. Shartsis, W. Capps and S. Spinner: J. Am. Ceram. Soc., 36 (1953), 35.

13) S. Takeuchi, T. Yamate and M. Kunugi: J. Soc. Mater. Sci. Jpn., 14 (1965), 59

14) M. Kunugi, A. Konishi, S. Takeuchi and T. Yamate: J. Soc. Mater. Sci. Jpn., 21 (1972), 10

15) L. Shartsis, W. Capps and S. Spinner: J. Am. Ceram. Soc., 36 (1953), 319.

16) G. H. Kaiura and J. M. Toguri: Phys. Chem. Glasses, 17 (1976), 62.

17) L. Shartsis and W. Capps: J. Am. Ceram. Soc., 35 (1952), 169.

18) K. Nagata, K. Ohira, H. Yamada and K. S. Goto: Metall. Trans. $B, 18 B$ (1987), 549 .

19) M. Derno, G. Herms and H. Steil: Phys. Status. Solidi., a93 (1986), K5.

20) E. M. Levin and H. F. McMurdie: Phase Diagrams for Ceramists, 1975 Supplement, ed. by M. K. Reser, Am. Ceram. Soc., Columbus, (1975), 89.

21) T. E. Faber and J. M. Ziman: Philos. Mag., 11 (1965), 153.

22) V. F. Sears: Atomic Energy of Canada Limited Report, No. AECL-8490, (1984).

23) N. Umesaki, N. Iwamoto, M. Takahashi, M. Tatsumisago, T. Minami and Y. Matsui: Trans. Iron. Steel Inst. Jpn., 28 (1988), 852.

24) Q. Xu, K. Kawamura and T. Yokokawa: J. Non-Cryst. Solids, 104 (1988), 261

25) D. L. Griscom: Borate Glasses (Mater. Sci. Res. Vol. 12), ed. by L. D. Pye, V. D. Fréchette and N. J. Kreidl, Plenum, New York, (1978), 11. 